\title{
Quality of life in patients with sickle cell disease
}

\author{
Qualidade de vida em portadores de doença falciforme \\ Calidad de vida en portadores de enfermedad falciforme
}

Adeline Soraya de O. da P. Menezes', Cláudio Arnaldo Len², Maria Odete E. Hilário³, Maria Teresa R. A. Terreri, Josefina Aparecida P. Braga ${ }^{4}$

\section{ABSTRACT}

Objective: To evaluate the quality of life in children and adolescents with sickle cell disease attending a blood reference center, and to assess the quality of life of their relatives.

Methods: Cross-sectional study that included 100 patients with sickle cell disease, which were divided into three subgroups according to age: 5 to $7(\mathrm{n}=18), 8$ to $12(\mathrm{n}=32)$, and 13 to 18 years-old ( $\mathrm{n}=50)$, and their parents. The Control Group included 50 healthy children and adolescents from a public local school, also divided into the same three age subgroups and their caregivers. The Pediatric Quality of life Inventory (PedsQL), version 4.0, was applied in both groups. The generic questionnaire Medical Outcomes Study 36 - Item Short-Form Health Survey (SF-36) was applied to the relatives. The answers were linearly transformed into a score and compared by nonparametric tests.

Results: The PedsQL scores of patients were significantly lower than those obtained in the Control Group $(p<0.0001)$ in all studied areas (physical, emotional, social skills, and school activities). Similarly, SF-36 scores applied to the patients' parents were lower than those obtained in the Control Group in all studied aspects $(p<0.0001)$.

Conclusions: Sickle cell disease affects the quality of life of children, adolescents, and their families. Patients sense restrictions in the emotional, social, family and physical aspects, among others.

Key-words: quality of life; anemia, sickle cell; children; adolescents.
RESUMO

Objetivo: Avaliar a qualidade de vida relacionada à saúde de crianças e adolescentes com doença falciforme assistidas em um hemocentro de referência e mensurar a qualidade de vida relacionada à saúde dos respectivos familiares.

Métodos: Estudo transversal e seccional com 100 pacientes portadores de doença falciforme, divididos em três subgrupos conforme a faixa etária: de 5 a $7(n=18)$, de 8 a 12 (n=32) e de 13 a 18 anos $(n=50)$ e com seus respectivos pais. O Grupo Controle foi composto por 50 crianças e adolescentes saudáveis de uma escola pública local, também divididos nos três subgrupos de idade e seus respectivos cuidadores. Foi aplicado o questionário genérico “Pediatric Quality of Life Inventory” (PedsQL), versão 4.0, em ambos os grupos. Aos familiares foi aplicado o questionário genérico Medical Outcomes Study 36-Item Short-Form Health Survey (SF-36). As respostas obtidas foram linearmente transformadas em um escore e comparadas com o auxílio de testes não paramétricos.

Resultados: Os escores dos pacientes no PedsQL foram inferiores àqueles do Grupo Controle $(p<0,0001)$ nos aspectos estudados (capacidades física, emocional, social e atividade escolar). Da mesma forma, os escores do SF-36 aplicados aos pais dos pacientes foram mais baixos que os de pais do Grupo Controle em todos os aspectos estudados $(p<0,0001)$.

Conclusões: A doença falciforme compromete a qualidade de vida das crianças, dos adolescentes e de suas respectivas famílias. Os pacientes percebem restrições nos aspectos emocional, social, familiar e físico, dentre outros.

Palavras-chave: qualidade de vida; anemia falciforme; crianças; adolescentes.
Instituição: Escola Paulista de Medicina (EPM) da Universidade Federal de São Paulo (Unifesp), São Paulo, SP, Brasil

${ }^{1}$ Mestre em Ciências pela EPM da Unifesp, São Paulo, SP, Brasil

${ }^{2}$ Livre-Docente em Pediatria pela Unifesp; Professor Adjunto do Departamento de Pediatria da EPM, Unifesp, São Paulo, SP, Brasil

${ }^{3}$ Livre-Docente em Pediatria pela Unifesp; Professora-Associada do Departamento de Pediatria da EPM, Unifesp, São Paulo, SP, Brasil

${ }^{4}$ Doutora em Pediatria pela Unifesp; Professora Adjunta do Departamento de Pediatria da EPM, Unifesp, São Paulo, SP, Brasil

\author{
Endereço para correspondência: \\ Claudio Arnaldo Len \\ Rua dos Otonis, 725 \\ CEP 0402-002 - São Paulo/SP \\ E-mail: claudiolen@gmail.com \\ Conflito de interesse: nada a declarar \\ Recebido em: 13/3/2012 \\ Aprovado em: 10/9/2012
}




\section{RESUMEN}

Objetivo: Evaluar la calidad de vida relacionada a la salud en niños y adolescentes con enfermedad falciforme asistidas en un servicio de hemoterapia de referencia y medir la calidad de vida relacionada a la salud de los respectivos familiares.

Métodos: Estudio transversal y seccional en 100 pacientes portadores de enfermedad falciforme, divididos en tres subgrupos conforme a la franja de edad: de 5 a $7(n=18)$, de 8 a $12(n=32)$ y de 13 a $18(n=50)$ años con sus respectivos padres. El Grupo Control fue compuesto por 50 niños y adolescentes sanos de una escuela pública local, también divididos en los mismos tres subgrupos de edad y sus respectivos cuidadores. Se aplicó el cuestionario genérico «Pediatric Quality of Life Inventory» (PedsQL), versión 4.0, a ambos grupos. A los familiares se aplicó el cuestionario genérico Medical Outcomes Study 36 - Item Short-Form Health Survey (SF-36). Las respuestas obtenidas fueron linealmente transformadas en un escore y comparadas con la ayuda de pruebas no paramétricas.

Resultados: Los escores de los pacientes en el PedsQL fueron inferiores a aquellos del Grupo Control $(p<0,0001)$ en los aspectos estudiados (capacidades física, emocional, social y actividad escolar). Del mismo modo, los escores del SF-36 aplicados a los padres de los pacientes fueron más bajos que los de padres del Grupo Control en todos los aspectos estudiados $(p<0,0001)$.

Conclusiones: La enfermedad falciforme compromete la calidad de vida de los niños, de los adolescentes y de sus respectivas familias. Los pacientes perciben restricciones en los aspectos emocional, social, familiar y físico, entre otros.

Palabras clave: calidad de vida; anemia falciforme; niños; adolescentes.

\section{Introduction}

Sickle cell disease (SCD) is a chronic hemolytic hereditary anemia resulting from a mutation in which valine substitutes for glutamic acid in codon 6 of the $\beta$-hemoglobin chain, which leads to the formation of hemoglobin S. This basic defect is the main cause of the various clinical signs and symptoms of this disease ${ }^{(1)}$. SCD is the result of a combination of hemoglobin $\mathrm{S}(\mathrm{HbS})$ with another abnormal hemoglobin, such as hemoglobin $\mathrm{C}(\mathrm{HbC})$, beta-thalassemia and $\mathrm{HbS}$, which characterize hemoglobinopathies HbSC, HbS beta-thalassemia and $\mathrm{HbSS}^{(2,3)}$. Sickle cell anemia is the most severe form of sickle cell disease. In Brazil, it is classified as a public health problem because of its high prevalence ${ }^{(4)}$.

SCD has high morbidity and mortality. It is characterized by acute clinical symptoms, such as painful vasculo-occlusive episodes, splenic sequestration and acute thoracic syndrome, that make the patient seek the emergency services frequently, and also by chronic signs, as it affects organs and systems. Survival and quality of life improvement for these patients is based on general and preventive measures ${ }^{(5)}$. Several changes affect the life of patients with SCD which force them to face limitations, frustrations and losses and to adapt to a new life style. These changes are necessary because of the use of medications, hospitalizations and lost working capacity. Because of these events, there may also be a variable impact on their health-related quality of life (HRQL) $)^{(6-8)}$.

HRQL is a construct made up of different elements: biological, social and relational, psychological and of functional autonomy. They come together for individuals to evaluate how much more or less quality their life has ${ }^{(9,10)}$. In the last decades, several instruments have been designed to measure quality of life of children ${ }^{(11)}$. The Pediatric Quality of Life Inventory (PedsQL) 4.0 stands out as a scale to measure quality of life of both healthy children and children with chronic diseases. This questionnaire has been recently translated and culturally validated for use in Brazilian children ${ }^{(12)}$. The Medical Outcomes Study 36-Item Short-Form Health Survey (SF-36) is a general instrument to evaluate quality of life, easy to administer and to understand.

This study used the SF-36 and the PedsQL questionnaires to measure HRQL of children and adolescents with SCD followed up in a reference blood center and to compare findings with those of a control group of the same age.

\section{Method}

This study was approved by the Ethics in Research Committee of the Escola Paulista de Medicina of the Universidade Federal de São Paulo (EPM/Unifesp) and the Hemocentro de Alagoas (HEMOAL), in Brazil. Patients and controls and their caregivers (parents and guardians) received information about the study and signed an informed consent term in the presence of the author.

This cross-sectional study included a convenience sample and was conducted from March to December 2009. Of 495 patients with SCD detected by hemoglobin electrophoresis who were registered in the blood center, only the children aged 5 to 18 years were included in the study. According 
to the database, there were 162 patients in that age group registered in HEMOAL. Patients and their caregivers were invited by the author to come to HEMOAL where meetings to explain the study were conducted and where they were asked to sign the informed consent term. Exclusion criteria were: physical comorbidities (stroke, femoral head avascular necrosis and lung disease) or mental diseases (cognitive development delay and psychic disorders) and absence caregiver during consultation. Exclusion criteria for patient parents were chronic or acute disease in the previous 30 days. A total of 100 patients were included in the study.

The control group had 50 healthy children and adolescents that studied in a public school in a suburb of Maceió, Brazil, whose socioeconomic status was the same as that of the patients. They were also subdivided into the same age groups, together with their parents or guardians.

Quality of life was measured using the SF-36 and the PedsQL 4.0 questionnaires in three stages.

\section{Stage 1}

The general PedsQL 4.0 ${ }^{(13)}$ questionnaire translated to Portuguese and adapted to the Brazilian culture was applied to the patients. This questionnaire has versions for four age groups: $2-4,5-7,8-12$ and $13-18$ years. Its domains evaluate problems such as physical capacity, emotional and social aspects and school activities. Items are score-reversed and linearly transformed using a 0 to 100 scale $(0=100$, $1=75,2=50$ and $4=0$ ), so that higher scores represent better quality of life ${ }^{(13)}$. In the administration of PedsQL 4.0, children were asked how much of each problem they had experienced in the previous month. In the reports of children aged 5 to 18 years and their parents, a five point scale was used $(0=$ never; $1=$ almost never; $2=$ sometimes; $3=$ often; and $4=$ almost always). For children aged 5 to 7 years, the scale was simplified to three points $(1=$ never; $2=$ sometimes; $3=$ many times, and each answer was given according to a visual analog scale with a happy, a neutral and a sad face.

\section{Stage 2}

The general SF-36 questionnaire translated to Portuguese and adapted to the Brazilian culture ${ }^{(14)}$ was applied to evaluate the impact of the disease on the patients' parents. SF-36 is a multidimensional questionnaire with 36 items divided into 8 scales or domains: functional capacity, physical aspects, pain, general health, vitality, social and emotional aspects and mental health. The final score ranges from 0 to 100 , where 0 corresponds to the worst general health and 100 , the best ${ }^{(14)}$.
The present instrument version has eight domains grouped into two components: physical and mental. Each item is evaluated by the sum of points (Likert-like scale), and values range from 0 to 100 points. The highest scores correspond to better quality of life. Scores are calculated according to the points of the items in each domain, as well as those of the components that are derivations of the related domains.

\section{Stage 3}

The questionnaires were applied to the control group of 50 children and adolescents ( 5 to 18 years) and their caregivers after the school board granted permission.

For statistic analyses, the Kolmogorov-Smirnov test was used, and results showed that the domain scores were not normally distributed. Therefore, the nonparametric MannWhitney test was used to compare domain values. All analyses were conducted using the Statistical Package for the Social Sciences (SPSS) 13.0.

\section{Results}

The group of patients had 64 girls and 36 boys, and 18 were aged 5 to 7 years, 32, 8 to 12 years; and 50, 13 to 18 years. The control group had 31 girls and 19 boys, and 11 were aged 5 to 7 years; 19,8 to 12 years; and 20, 13 to 18 years.

PedsQL 4.0 scores for the patients and controls are shown in Table 1. Patient scores in all aspects were significantly lower than those of controls $(p<0.0001)$.

HRQL results for the parents are shown in Table 2. Parents' scores, in all aspects, were significantly lower than those of the control participants $(p<0.0001)$.

\section{Discussion}

This study found that SCD is associated with limitations in different aspects of HRQL, particularly physical, social, emotional and school aspects. In all those aspects, PedsQL 4.0 scores were lower than those found for normal children and adolescents of the same age.

This negative impact, particularly in the physical aspect, is associated with pain due to SCD and the overload of work due to the care and attention directed to the child or adolescent with the disease $\mathrm{e}^{(15)}$. Pain is the complication that has the greatest impact on HRQL of patients with SCD and their families, although its intensity is variable and depends on individual characteristics, family and cultural context and the multiprofessional team that is responsible for their health care ${ }^{(6,16)}$. 
Table 1 - Score of the Pediatric Quality of Life Inventory (PedsQL) 4.0 for the three age groups of children and adolescents with sickle cell and healthy controls

\begin{tabular}{|c|c|c|c|c|c|}
\hline & \multicolumn{2}{|c|}{ Group of patients } & \multicolumn{2}{|c|}{ Control group } & \multirow[b]{2}{*}{$p$-value } \\
\hline & Mean & $\begin{array}{l}\text { Standard } \\
\text { Deviation }\end{array}$ & Mean & $\begin{array}{l}\text { Standard } \\
\text { Deviatio }\end{array}$ & \\
\hline $5-7$ years & & & & & \\
\hline Physical & 56.16 & 12.33 & 91.81 & 9.36 & $<0.0001$ \\
\hline Emotional & 70.55 & 13.04 & 96.36 & 9.24 & $<0.0001$ \\
\hline Social & 79.44 & 12.11 & 98.18 & 6.03 & $<0.0001$ \\
\hline School & 68.88 & 11.82 & 93.63 & 12.06 & $<0.0001$ \\
\hline $8-12$ years & & & & & \\
\hline Physical & 48.37 & 13.77 & 94.10 & 6.64 & $<0.0001$ \\
\hline Emotional & 75.31 & 12.11 & 92.89 & 7.69 & $<0.0001$ \\
\hline Social & 72.65 & 9.50 & 95.00 & 7.07 & $<0.0001$ \\
\hline School & 65.15 & 15.78 & 97.10 & 6.08 & $<0.0001$ \\
\hline $13-18$ years & & & & & \\
\hline Physical & 42.86 & 13.77 & 94.55 & 6.31 & $<0.0001$ \\
\hline Emotional & 71.50 & 13.41 & 96.00 & 6.40 & $<0.0001$ \\
\hline Social & 72.10 & 11.56 & 95.50 & 8.09 & $<0.0001$ \\
\hline School & 57.60 & 17.61 & 94.50 & 9.30 & $<0.0001$ \\
\hline
\end{tabular}

Table 2 - Score of the Medical Outcomes Study 36-Item Short-Form Health Survey (SF-36) for caregivers of patients with sickle cell disease and for controls

\begin{tabular}{|c|c|c|c|c|c|c|c|c|c|}
\hline \multirow[b]{2}{*}{ Domain } & \multicolumn{4}{|c|}{ Group of patients } & \multicolumn{4}{|c|}{ Control group } & \multirow[b]{2}{*}{$p$-value } \\
\hline & Minimum & Maximum & Mean & $\begin{array}{l}\text { Standard } \\
\text { deviation }\end{array}$ & Minimum & Maximum & Mean & $\begin{array}{l}\text { Standard } \\
\text { deviation }\end{array}$ & \\
\hline Functional capacity & 15.0 & 100.0 & 54.6 & 17.2 & 75.0 & 100.0 & 92.6 & 9.3 & $<0.0001$ \\
\hline $\begin{array}{l}\text { Limitations due to } \\
\text { physical aspects }\end{array}$ & 0.0 & 100.0 & 66.8 & 41.6 & 100.0 & 100.0 & 100.0 & 0.0 & $<0.0001$ \\
\hline Pain & 0.0 & 70.0 & 32.5 & 16.1 & 50.0 & 70.0 & 51.6 & 5.5 & $<0.0001$ \\
\hline General health & 10.0 & 95.0 & 62.4 & 20.7 & 90.0 & 100.0 & 96.5 & 4.2 & $<0.0001$ \\
\hline Vitality & 10.0 & 85.0 & 56.2 & 16.2 & 70.0 & 75.0 & 72.2 & 2.5 & $<0.0001$ \\
\hline Social aspects & 12.0 & 100.0 & 77.5 & 15.6 & 87.5 & 100.0 & 99.0 & 3.4 & $<0.0001$ \\
\hline $\begin{array}{l}\text { Limitations due to } \\
\text { emotional aspects }\end{array}$ & 0.0 & 100.0 & 74.9 & 36.6 & 100.0 & 100.0 & 100.0 & 0.0 & $<0.0001$ \\
\hline Mental health & 40.0 & 96.0 & 69.5 & 17.9 & 96.0 & 100.0 & 97.9 & 2.0 & $<0.0001$ \\
\hline
\end{tabular}

The negative repercussion in the mental components and domain may be a result of the excessive concerns that caregivers have with the patient's health, of the difficulty in dealing with the disease symptoms and of the possible changes in the family routine because of medical treatments and frequent hospitalizations. These findings indicate that healthcare workers should have a global understanding of patients and caregivers to promote strategies that have a higher possibility of improving well-being and health ${ }^{(17,18)}$.

A chronic disease in childhood generates the need of greater parental participation in the care provided to the child and adaptation to new situations along time ${ }^{(19)}$. Even 
healthy individuals experience changes in their expectations and in the feeling of well-being along life, and adolescents are less happy with their family relationships than children ${ }^{(20)}$.

Palermo et al ${ }^{(21)}$ reported a greater commitment with physical health among adolescents with SCD than among children when they evaluated HRQL of children and adolescents according to their parent. However, Panepinto et $a^{(22)}$ did not find any significant differences in HRQL when comparing the scores of children and adolescents with SCD, neither in the physical nor in the psychosocial domains.

According to Silver $e$ et $l^{(23)}$ and Sloper ${ }^{(24)}$, a chronic disease in childhood involves the risk of psychological and psychosocial problems for parents and family members along the years. In a study conducted by Moskowitz et al ${ }^{(25)}$, the mothers of children with SCD had a higher risk of depression than the mothers of healthy children. Caregivers of patients with SCD usually experience feelings of guilt, anxiety and depression associated with the hereditary aspect of the disease, the medical follow-up and the social and financial demands posed by a chronic disease. Therefore, the caregiver's well being may be compromised, particularly the mental construct. These results support the need to give greater attention and promote more intensively the mental health of these individuals ${ }^{(17,18,26)}$. Socioeconomic factors affect the quality of life of patients ${ }^{(27)}$ with sickle cell disease, as already described in the study conducted by Felix et al ${ }^{(28)}$ in Uberaba, Brazil.

The socioeconomic condition is relatedrelated to quality of life, which might have affected the results of this study. However, the control group had the same socioeconomic conditions, which minimized its impact.

In the group of patients with SCD, the survey was not conducted with all patients that were followed up in HEMOAL due to logistic limitations. Moreover, the exclusion of patients that did not come to the consultation may have affected results, because those patients may have missed because they were hospitalized or were fine and decided not to come to the consultation, or, still, because they were lost to follow-up. The number of painful crises and transfusions in the previous 12 months in children and adolescents, factors that are directly associated with quality of life, were not included in the analysis because that information was not provided by the patients' parents or family member and was not available in the patients charts, as they were not dealt with in HEMOAL. Children and adolescents with SCD are individuals exposed to several factors that may determine a reduction in the physical or psychosocial domains of quality of life. Educational efforts directed to healthcare workers and family members of patients with SCD should be increased to identify the problems associated with their health. Therefore, instruments that can detect some type of risk, such as the PedsQL 4.0 , are essential for healthcare workers involved in the treatment of this population. They provide the necessary instruments to interfere precisely in one or more aspects.

The act of taking care demands an overload of attention and intense dedication and, as the family is the main actor in this role, the healthcare team has to ensure that parents have the conditions to reorganize their lives physically and emotionally in face of this new phase of responsibility, because caregivers are the healthcare workers' best allies in the treatment of their patients' health.

Our findings confirmed the need to conduct a more detailed analysis of HRQL of patients with sickle cell anemia. The results of this study showed significant differences between the groups under study, which reinforced the need to promote prevention programs and organize multiprofessional teams.

\section{References}

1. Steinberg MH. Pathophysiologically based drug treatment of sickle cell disease. Trends Pharmacol Sci 2006;27:204-10.

2. Brasil. Ministério da Saúde. Agência Nacional de Vigilância Sanitária [homepage on the Internet]. Manual de diagnósticos e tratamento de doenças falciformes. Brasília: ANVISA, 2002 [cited 2012 Nov 20]. Available from: http:// www.anvisa.gov.br

3. Brasil. Ministério da Saúde. Secretaria de Atenção à Saúde. Departamento de Atenção Especializada [homepage on the Internet]. Manual da anemia falciforme para a população. [Série A. Normas e Manuais Técnicos]. Brasília: Ministério da Saúde, 2007 [cited 2012 Nov 20]. Available from: http://www. saude.gov.br/editora

4. Cançado RD, Jesus JA. Sickle cell disease in Brazil. 2007;29:203-6.
5. Braga JA. General measures in the treatment of sickle cell disease. Rev Bras Hematol Hemoter 2007;29:233-8.

6. Tostes MA, Braga JA, Len CA, Hilário MO. Avaliação de dor em crianças e adolescentes portadores de doença falciforme. Rev Cienc Med (Campinas) 2008;17:141-7.

7. Pereira SA, Cardoso CS, Brener S, Proietti AB. Sickle cell disease and quality of life: a study on the subjective perception of patients from the Fundação Hemominas, Minas Gerais, Brazil. Rev Bras Hematol Hemoter 2008;30:411-6.

8. Brandow AM, Brousseau DC, Pajewski NM, Panepinto JA. Vaso-occlusive painful events in sickle cell disease: impact on child well-being. Pediatr Blood Cancer 2010;54:92-7. 
9. Seidl EM, Zannon CM. Quality of life and health: conceptual and methodological issues. Cad Saude Publica 2004;20:580-8.

10. Minayo MC, Hartz ZM, Buss PM. Quality of life and health: a necessary debate. Cienc Saude Colet 2000;5:7-18.

11. Savoia MG. Instrumentos para avaliação de eventos vitais e de estratégias de enfrentamento (coping) em situações de estresse. In: Gorenstein C, Andrade LH, Zuardi AW, editors. Escalas de avaliação clínica em psiquiatria e psicofarmacologia. São Paulo: Lemos; 2000, p. 377-85.

12. Klatchoian DA, Len CA, Terreri MT, Silva CM, Itamoto C, Ciconelli RM et al. Quality of life of children and adolescents from São Paulo: reliability and validity of the Brazilian version of the pediatric quality of life inventory ${ }^{\mathrm{TM}}$ version 4.0 generic core scales. J Pediatr (Rio J) 2008;84:308-15.

13. Varni JW, Seid M, Rode CA. The PedsQL: measurement model for the pediatric quality of life inventory. Med Care 1999;37:126-39.

14. Ciconelli RM, Ferraz MB, Santos W, Meinão I, Quaresma MR. BrazilianPortuguese version of the SF-36. A reliable and valid quality of life outcome measure. Rev Bras Reumatol 1999;39:143-50.

15. McGrath PJ, Finley GA. A Medição da dor. In: Nestlé, editor. A dor na infância. São Paulo: Nestlé; 2000. p. 14-22.

16. Shapiro BS, Dinges DF, Orne EC, Bauer N, Reilly LB, Whitehouse WG et al. Home management of sickle cell-related pain in children and adolescents: natural history and impact on school attendance. Pain 1995;61:139-44.

17. Castro EK, Piccinini CA. A experiência de maternidade de mães de crianças com e sem doença crônica no segundo ano de vida. Estud Psicol (Natal) 2004;9:89-99.

18. Sales E. Family burden and quality of life. Qual Life Res 2003;12 (Suppl 1):33-41.
19. Goldbeck L. The impact of newly diagnosed chronic paediatric conditions on parental quality of life. Qual Life Res 2006;15:1121-31.

20. Goldbeck L, Schmitz TG, Besier T, Herschbach P, Henrich G. Life satisfaction decreases during adolescence. Qual Life Res 2007;16:969-79.

21. Palermo TM, Schwartz L, Drotar D, McGowan K. Parental report of healthrelated quality of life in children with sickle cell disease. J Behav Med 2002;25:269-83.

22. Panepinto JA, O'Mahar KM, DeBaun MR, Loberiza FR, Scott JP. Health-related quality of life in children with sickle cell disease: child and parent perception. Br J Haematol 2005;130:437-44.

23. Silver EJ, Westbrook LE, Stein RE. Relationship of parental psychological distress to consequences of chronic health conditions in children. J Pediatr Psychol 1998;23:5-15.

24. Sloper P. Predictors of distress in parents of children with cancer: a prospective study. J Pediatr Psychol 2000;25:79-91.

25. Moskowitz JT, Butensky E, Harmatz P, Vichinsky E, Heyman MB, Acree M et al. Caregiving time in sickle cell disease: psychological effects in maternal caregivers. Pediatr Blood Cancer 2007;48:64-71.

26. Olley LB, Brieger WR, Olley BO. Perceived stress factors and coping mechanisms among mothers of children with sickle cell disease in western Nigeria. Health Educ Res 1997;12:161-70.

27. Panepinto JA, Pajewski NM, Foerster LM, Sabnis S, Hoffmann RG. Impact of family income and sickle cell disease on the health-related quality of life of children. Qual Life Res 2009;18:5-13.

28. Felix AA, Souza HM, Ribeiro SB. Epidemiologic and social aspects of sickle cell disease. Rev Bras Hematol Hemoter 2010;32:203-8. 